\title{
Test positivity for Maedi-Visna virus and Mycobacterium avium ssp. paratuberculosis in Sarda ewes: Effects on milk composition and coagulation traits and heritability estimates for susceptibility
}

\author{
Michele Pazzola, ${ }^{1 *}(\bullet)$ Giantonella Puggioni, ${ }^{2} \odot$ Maria N. Ponti, ${ }^{2} \odot$ Rosario Scivoli, ${ }^{2} \oplus$ Maria L. Dettori, ${ }^{1} \oplus$ \\ Alessio Cecchinato, ${ }^{3}$ (I) and Giuseppe M. Vacca ${ }^{1}$ (I) \\ ${ }^{1}$ Department of Veterinary Medicine, University of Sassari, via Vienna 2, 07100 Sassari, Italy \\ ${ }^{2}$ Istituto Zooprofilattico Sperimentale della Sardegna "G. Pegreffi," Via Vienna 2, 07100 Sassari, Italy \\ ${ }^{3}$ Department of Agronomy, Food, Natural resources, Animals and Environment (DAFNAE), University of Padova, viale dell'Università 16, \\ 35020 Legnaro (PD), Italy
}

\section{ABSTRACT}

Maedi-Visna virus (MVV) and Mycobacterium avium ssp. paratuberculosis (MAP) are two pathogens that cause chronic, production-limiting diseases in dairy sheep. Although they are present worldwide, there are no detailed reports on their actual effects on milk traits in the literature. This study was designed to investigate the effects of test positivity to MVV and MAP on ovine milk yield, composition and coagulation properties, and curd-firming over time $\left(\mathrm{CF}_{\mathrm{t}}\right)$ variables in clinically healthy animals at the field level. The additive genetic variation and heritabilities of MVV and MAP positivity were also estimated. Milk samples were collected from 1,079 Sarda sheep kept on 23 farms, and pedigree information was obtained from the flock book. Milk yield was also recorded on the sampling date. Positivity for MVV and MAP was determined from milk samples using indirect ELISA test kits. Milk composition traits were measured by spectroscopy, milk coagulation properties were measured with a Formagraph (Foss Italia, Padua, Italy), and $\mathrm{CF}_{\mathrm{t}}$ traits were calculated using the data from the Formagraph diagram. The effects of MVV and MAP positivity on milk traits were determined through a set of mixed linear models, which took into account various sources of variation, such as days in milk, parity, and flock effects, and included the effects (positive or negative) of the 2 pathogens. A Bayesian threshold sire model with sire relationship was used to estimate genetic variation and heritability. The overall animal prevalence of MVV-positive ewes was 43.6\%; on only 1 farm of the 23 tested were all sampled ewes negative. An overall animal prevalence of $10.6 \%$ was recorded for MAP, with 4 farms at $0 \%$. Positivity for

Received December 9, 2019.

Accepted June 2, 2020.

*Corresponding author: pazzola@uniss.it
MVV significantly affected the logarithmic score of the bacterial count, curd firmness after $30 \mathrm{~min}$ and $45 \mathrm{~min}$, and the curd-firming instant rate constant. We found significant effects of MAP infection on milk composition, $\mathrm{pH}$, and rennet coagulation time. The mean of the posterior distributions of heritability estimates on the liability scale was 0.15 for MAP and 0.07 for MVV. Our results demonstrate that only a few traits are negatively affected by MVV and MAP positivity, and that there is exploitable genetic variation in MVV and MAP susceptibility in dairy sheep.

Key words: Maedi-Visna virus, Mycobacterium avium ssp. paratuberculosis, milk trait, heritability estimate

\section{INTRODUCTION}

Sheep farming is an important agricultural activity worldwide with specializations in milk, meat, and wool production. Some of the economic losses in sheep farming are caused by diseases of viral and microbial origin. These have been reported to have higher incidences and morbidity rates in sheep than in other livestock species (Roger, 2008). However, many infectious agents are often silent or cause chronic diseases.

Animal diseases may reduce a farm's gross income by up to $20 \%$ (Jarvis and Valdes-Donoso, 2018), with losses more evident and quantifiable in acute outbreaks. The effects of chronic diseases, whether direct or indirect, on the economic performance of farms are often underestimated. Direct losses are mainly represented by reductions in the value of the primary products, such as lower milk yields and less favorable milk composition, as well as by reduced fertility, increased susceptibility to other diseases, and costs of testing and treatment. Indirect losses may be incurred from local and international trade restrictions (Whittington et al., 2019).

Maedi-Visna virus (MVV) was the first member of a new category - the small ruminant lentiviruses 
(SRLV) - to be discovered. It was first described in 1954 during an outbreak in Iceland (Straub, 2004). Maedi-Visna virus is characterized by a lifelong infection, which causes a slow progressive interstitial pneumonia (maedi) and a demyelinating encephalomyelitis (visna) (Arnarson et al., 2017), although pathological signs are also noticeable in the mammary gland (Benavides et al., 2013). Test-positive sheep are often asymptomatic in the preclinical period, which can last for several years, and around 25 to $30 \%$ of infected sheep show clinical signs (Christodoulopoulos, 2006). Nevertheless, MVV is a disease listed by the World Organization for Animal Health (OIE, 2019) and its indirect negative impact on reproductive and productive performance has been reported in the literature (Benavides et al., 2013).

Paratuberculosis (PTB), also known as Johne's disease, is a chronic disease of ruminants caused by Mycobacterium avium ssp. paratuberculosis (MAP). Because of possible transmission from animals to humans, MAP is considered a zoonotic pathogen (Garvey, 2018), although the association with the inflammatory bowel diseases in humans (Crohn's disease) is yet to be officially confirmed (Windsor, 2015). Furthermore, in many countries, PTB is "non-notifiable" and control measures are therefore not in place (Begg and Whittington, 2010). The most common lesion occurring in PTB is a thickening of the mucosa of the small intestine with clinical signs often limited to chronic weight loss, sometimes with diarrhea (Begg and Whittington, 2010). Mycobacterium avium ssp. paratuberculosis is present in sheep worldwide, with high levels of prevalence, sometimes as much as $70 \%$ at the flock level (Bauman et al., 2019).

Both paratuberculosis and MVV have a long incubation period, a characteristic that allowed these diseases to evade quarantine controls in Iceland in the 1930s (Begg and Whittington, 2010), which means individual animals are often co-infected with MAP and SRLV (Stonos et al., 2017). Like MVV and other chronic diseases, many studies have found PTB to be associated with loss of productive performance (Begg and Whittington, 2010) and, as a consequence, loss of gross income by farms (Sardaro et al., 2017; Garvey, 2018; Bauman et al., 2019).

Given the above, control and eradication programs are difficult but nonetheless have moderate to high success rates in countries worldwide for both MVV (Straub, 2004) and MAP (Whittington et al., 2019). Selection for disease-resistant animals may be a means of increasing the average ability of offspring to resist MVV and MAP infection, making this a viable option for controlling these pathogens. Although some studies have reported the effects of genetic markers for resistance or predisposition (Straub, 2004; McRae et al., 2016), to the best of our knowledge, no systematic study of the genetics of susceptibility to MAV and MAP infection in Sarda dairy sheep has been undertaken. Comprehensive genetic evaluation is a crucial step in improving genetic resistance to these infections.

Therefore, the objective of this study was to assess the effects of testing positive for MVV and MAP on ovine milk yield and composition, milk coagulation properties (MCP), and curd-firming over time $\left(\mathbf{C F}_{\mathrm{t}}\right)$ traits, and to estimate genetic variation and heritabilities of MVV and MAP positivity in clinically healthy animals at the field level.

\section{MATERIALS AND METHODS}

\section{Sampled Farms and Animals}

The present study was a part of a larger investigation regarding phenotypic and genetic traits of ovine milk. Samples were collected from 1,079 sheep kept on 23 farms. A detailed description of animals and farms is reported in Pazzola et al. (2014). Farms were located in the territory of Sardinia, an insular region of Italy; all the ewes were officially registered in the flock book of the Sarda, a dairy specialized breed from Sardinia. Samples were collected concurrently with official sampling procedures for performance controls of the Sarda flock book by the interprovincial and provincial farmers' associations of Sardinia (Italy). The number of sampled ewes at each of the 23 farms ranged from 22 to 76 (Table 1); age of sampled ewes was from 1 to $9 \mathrm{yr}$ (mean 2.56); parity of ewes was between 1 and 9, and DIM (days after lambs' weaning) between 30 and 275 . Each ewe was submitted to a veterinary examination, as described in Pazzola et al. (2018a): in brief, ewes showing any clinical sign of diseases were discarded, and those showing no clinical signs were declared clinically healthy and sampled. Hence, the sampling method was not randomized because the farms were those enrolled in the Sarda flock book, and ewes sampled at farms were exclusively those declared clinically healthy.

Each ewe was individually sampled in a single day (one sampling day for each flock). Milk samples were collected during the afternoon milking in sterile plastic containers of $200 \mathrm{~mL}$ and refrigerated at $4^{\circ} \mathrm{C}$ until milk analysis; daily milk yield was the sum of morning plus evening milk yield of the same sampling day.

Pedigree information was supplied by the Flock Book Society of Italian sheep and goat breeders (Asso. Na.Pa.) and included ewes with phenotypic records for the investigated traits and all their known ancestors. The genetic structure was the same as described in Bittante et al. (2017). In brief, each animal with phe- 
Table 1. Farms, flock size, ewes at each farm tested for Maedi-Visna virus (MVV) and Mycobacterium avium ssp. paratuberculosis (MAP), number of positive ewes, and prevalence (\%) for 1,079 Sarda ewes in 23 farms

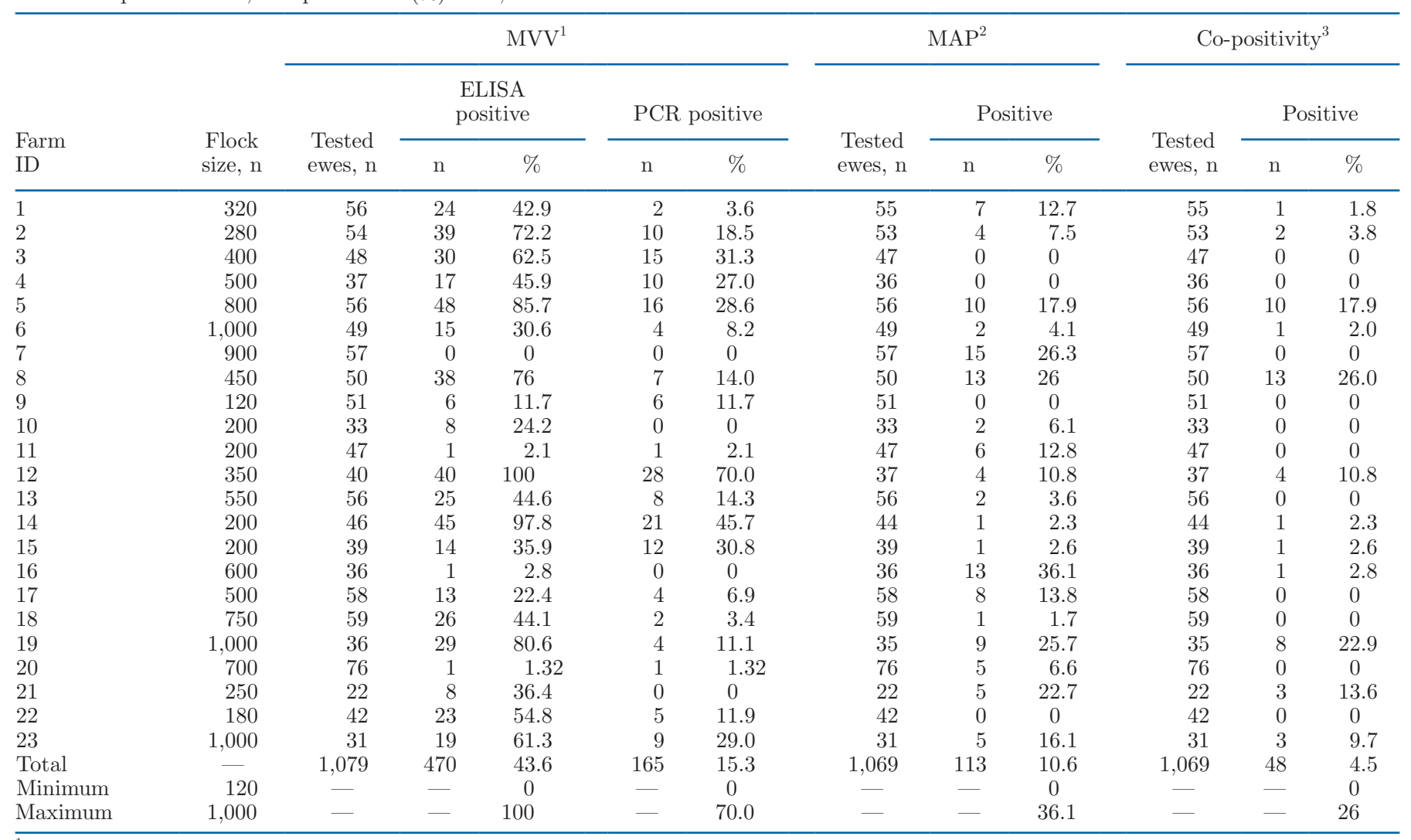

${ }^{1}$ Maedi-Visna indirect ELISA positivity evaluated using the Eradikit SRLV Screening Kit (In3Diagnostic, Torino, Italy); Maedi-Visna virus direct PCR positivity evaluated using the nested PCR method by Grego et al. (2007).

${ }^{2}$ Mycobacterium avium ssp. paratuberculosis indirect positivity using the ID Screen Paratuberculosis Indirect Screening test and ID Screen Paratuberculosis Indirect Confirmation test (ID Vet, Grabels, France).

${ }^{3}$ Both MVV and MAP indirect positivity.

notypic records had at least 4 known ancestors in the pedigree data (4,785 records). Sires numbered 725 and, of these, 121 had progeny with records in the data set (each sire having between 3 and 40 daughters).

\section{Infectious Diagnostic Tests}

Each individual milk sample was kept at $4^{\circ} \mathrm{C}$, tested within $24 \mathrm{~h}$ of collection, and analyzed for MVV and MAP positivity. Two tests were performed to detect Maedi-Visna positivity. The indirect test was based on detection of MVV antibodies in milk samples, using the Eradikit SRLV Started Kit (In3Diagnostic, Turin, Italy) according to the manufacturer's instructions. It is a highly sensitive and specific ELISA test (Michiels et al., 2018a), with plates coated with recombinant antigens including a mixture of A (MVV-like), B [caprine arthritis encephalitis virus (CAEV)-like], and E (Roccaverano-strain) SRLV viral genotypes. Samples were considered positive when the optical density (OD) value was equal or above the cut-off value calculated using the formula

$$
\begin{gathered}
100 \times\left(\mathrm{OD}_{\text {sample }}-\mathrm{OD}_{\text {negative control }}\right) / \\
\left(\mathrm{OD}_{\text {positive control }}-\mathrm{OD}_{\text {negative control }}\right) .
\end{gathered}
$$

All samples showing a value $\geq 40 \%$ were considered as positive. To identify the circulating viral genotype, all positive samples were tested with Eradikit SRLV Genotyping kit (In3Diagnostic) according to the manufacturer's instructions; this ELISA plate is coated with a mixture of different antigens belonging to a single SRLV genotype (A, B, and E). Because a small percentage of animals infected with lentiviruses do not produce detectable virus-specific antibodies, PCR tests have been developed to distinguish direct positive results in antibody-negative animals (de Andrés et al., 2005; González et al., 2005). In the present study, to detect MVV PCR-positive animals, milk samples were analyzed using a nested PCR amplifying sequences 
( $\sim 800$ bp long) of SRLV gag-pol genes, in accordance with the method reported by Grego et al. (2007).

To detect MAP positivity, we used only the indirect method. Anti-MAP antibodies were investigated in milk samples using the ID Screen Paratuberculosis Indirect Screening test and ID Screen Paratuberculosis Indirect Confirmation test (ID Vet, Grabels, France). Both kits have a preadsorption step with Mycobacterium phlei antigens to limit cross reactions with other mycobacteria. All samples that were positive after screening were later analyzed using the confirmation test. Results were expressed as percentage of sample-to-positive ratio $(\mathrm{S} / \mathrm{P})$ calculated using the formula

$$
\begin{gathered}
100 \times\left(\mathrm{OD}_{\text {sample }}-\mathrm{OD}_{\text {negative control }}\right) / \\
\left(\mathrm{OD}_{\text {positive control }}-\mathrm{OD}_{\text {negative control }}\right)
\end{gathered}
$$

for the screening test, and

$$
100 \times\left(\text { net } \mathrm{OD}_{\text {sample }}\right) /\left(\text { net } \mathrm{OD}_{\text {positive control }}\right)
$$

for the confirmation test. The cut-off limits recommended by the manufacturer for both screening and confirmation tests were used; milk samples showing $>30 \% \mathrm{~S} / \mathrm{P}$ were declared MAP-positive.

\section{Analysis of Milk Composition and Coagulation Properties}

Milk composition (fat, protein, casein, lactose, and pH) was measured using a MilkoScan FT6000 milk analyzer (Foss Electric A/S, Hillerød, Denmark), according to FIL-IDF recommendations (IDF, 2013), and calibrated for ewe milk at the Milk Laboratory of the Regional Farmers Association of Sardinia (Oristano, Italy). Somatic cell count was measured by using a Fossomatic 5000 somatic cell counter (Foss Electric A/S) according to IDF (2006) and transformed into the logarithmic SCS $\left[\mathrm{SCS}=\log _{2}\left(\mathrm{SCC} \times 10^{-5}\right)+3\right.$ ] as reported by Shook (1993). Total bacterial count (TBC) was measured using a BactoScan FC150 analyzer (Foss Electric A/S) according to IDF (2000) and transformed into the logarithmic bacterial count $\left[\mathbf{L B C}=\log _{10}\right.$ (TBC/1,000)] as reported by ISO/IDF (2004).

The Formagraph instrument (Foss Italia, Padua, Italy) was used to measure MCP. The Formagraph records the movement of loop pendula immersed in oscillating samples of coagulating milk and the resulting drag force of milk clots, according to the method first reported by McMahon and Brown (1982). Milk samples at $35^{\circ} \mathrm{C}$ were mixed with a rennet solution (Hansen Naturen Plus 215; Pacovis Amrein AG, Bern, Switzerland) diluted in distilled water to obtain a solution at $1.2 \%$ (wt/vol), with a final value of 0.0513 international milk clotting units (IMCU) per mL of milk, and submitted to a $60-$ min lactodynamographic analysis. The MCP measured from the Formagraph, also named single-point traits, were rennet coagulation time (RCT, min), as the time between rennet addition and coagulation; curd-firming time $\left(\mathbf{k}_{\mathbf{2 0}}, \mathbf{m i n}\right)$, as the time between coagulation and the width of curd firmness at $20 \mathrm{~mm}$; and the width of curd firmness 30, 45, and 60 min after rennet addition $\left(\mathbf{a}_{30}, \mathbf{a}_{45}\right.$, and $\left.\mathbf{a}_{60}, \mathrm{~mm}\right)$.

The $\mathrm{CF}_{\mathrm{t}}$ traits were measured from the width of the Formagraph diagram (curd firmness, CF) recorded by the pendula immersed in coagulating milk samples (one value every $15 \mathrm{~s}, 240$ in the 60 -min analysis). The $\mathrm{CF}_{\mathrm{t}}$ parameters can better describe the whole progression of milk coagulation stages (first gelation, progressive firming of the gel, and the syneresis process). During syneresis, contraction of the network of protein micelles causes the expulsion of whey and the formation of fresh curd (Vacca et al., 2015). Because of the faster coagulation and specific syneresis, $\mathrm{CF}_{\mathrm{t}}$ traits are more effective than single-point MCP to investigate ewe and goat milk (Vacca et al., 2015; Pazzola et al., 2018b). The 4-parameter model reported by Bittante et al. (2013), modified for ewe milk by Cipolat-Gotet et al. (2018), was used to analyze the $\mathrm{CF}$ values:

$$
\mathrm{CF}_{\mathrm{t}}=\mathrm{CF}_{\mathrm{P}} \times\left(1-\mathrm{e}^{-\mathrm{k}_{\mathrm{CF}} \times\left(\mathrm{t}-\mathrm{RCT}_{\mathrm{eq}}\right)}\right) \times \mathrm{e}^{\mathrm{k}_{\mathrm{SR}} \times\left(\mathrm{t}-\mathrm{RCT}_{\mathrm{eq}}\right)},
$$

in which $\mathrm{CF}_{\mathrm{t}}$ is the curd firmness at time $\mathrm{t}(\mathrm{mm}), \mathrm{CF}_{\mathrm{P}}$ is the asymptotic potential maximum value of curd firmness $(\mathrm{mm}), \mathrm{k}_{\mathrm{CF}}$ is the curd-firming instant rate constant $\left(\% \times \min ^{-1}\right), \mathrm{k}_{\mathrm{SR}}$ is the curd syneresis instant rate constant $\left(\% \times \min ^{-1}\right)$, and $\mathrm{RCT}_{\text {eq }}$ is the rennet coagulation time estimated by the model (min). The $\mathrm{CF}_{\mathrm{t}}$ model parameters were estimated by a curvilinear regression and PROC NLIN of SAS software (version 9.4, SAS Institute Inc., Cary, NC). The parameters of each individual equation were estimated using the Marquardt iterative method (350 iterations and a $10^{-5}$ level of convergence). Other derived $\mathrm{CF}_{\mathrm{t}}$ parameters are maximum curd firmness recorded during the analysis $\left(\mathbf{C F}_{\max }\right)$ and the time from rennet addition to the attainment of the $\mathrm{CF}_{\max }\left(\mathbf{t}_{\max }\right)$.

\section{Statistical Analysis}

Phenotypic Analysis. Traits regarding daily milk yield and milk composition (fat, protein, casein, lactose, $\mathrm{pH}, \mathrm{SCS}$, and LBC) were analyzed using the MIXED procedure (SAS version 9.4, SAS Institute Inc.) and the following model: 


$$
\begin{aligned}
Y_{\text {hijklm }} & =\mu+D I M_{h}+\text { Parity }_{i}+M V V_{j} \\
& +M A P_{k}+\text { Farm }_{l}+e_{\text {hijklm }},
\end{aligned}
$$

where $Y_{\text {hijklm }}$ is the observed trait; $\mu$ is the overall intercept of the model; $D I M_{h}$ is the fixed effect of the $h$ th class of days in milk ( $h=1$ to 5 ; class 1: $\leq 80$ d, 75 ewes; class 2: 81-120 d, 359 ewes; class 3: 121-160 d, 267 ewes; class 4: 161-200 d, 306 ewes; class 5: $\geq 201 \mathrm{~d}$, 72 ewes); Parity $_{i}$ is the fixed effect of the $i$ th parity ( $i$ $=1$ to 4; class 1: first parity, 447 ewes; class 2: second parity, 206 ewes; class 3: third parity, 203 ewes; and 4: fourth parity or more, 223 ewes); $M V V_{j}$ is the fixed effect of the $j$ th class of the test for $\operatorname{MVV}(j=1$ to 2 ; class 1: negative; class 2: positive); $M A P_{k}$ is the fixed effect of the $m$ th class of the test for MAP ( $m=1$ to 2; class 1: negative; class 2: positive); $\mathrm{Farm}_{l}$ is the random effect of the $l$ th farm $(l=1$ to 23$)$; and $e_{h i j k l m}$ is the random residual $\sim N\left(0, \sigma_{e}^{2}\right)$, where $\sigma_{e}^{2}$ is the residual variance.

Traits measured by the lactodynamograph analysis (MCP) and curd-firming modeling $\left(\mathrm{CF}_{\mathrm{t}}\right)$ were analyzed using a further model [2], with the same effects of model [1] plus the random effect of the measuring unit (pendulum) of the lactodynamograph instrument $(\mathrm{n}=$ 1 to 10$)$.

Genetic Analysis. A threshold model (Wright, 1934; Gianola, 1982; Sorensen et al., 1995) was used for the analysis of MVV and MAP positivity as a binary outcome. The threshold model postulates an underlying continuous random variable $\left(\lambda_{i}\right)$, called liability, that takes values above (or below) an arbitrarily fixed threshold $(\tau)$ when linked to nonpositive (or positive) animals:

$$
y_{i} \mid \lambda_{i}, \tau \sim I\left(y_{i}=0\right) I\left(\lambda_{i}<\tau\right)+I\left(y_{i}=1\right) I\left(\lambda_{i}>\tau\right),[3]
$$

where $I(\cdot)$ is an indicator function with argument as defined within parentheses. The indicator function has a value of 1 if the evaluated expression is true and a value of 0 otherwise. The vector of liabilities was assumed to be sampled from a normal distribution:

$$
\lambda \mid \boldsymbol{\beta}, \mathbf{h}, \mathbf{u} \sim N\left(\mathbf{X} \boldsymbol{\beta}+\mathbf{Z}_{1} \mathbf{h}+\mathbf{Z}_{2} \mathbf{u}, \mathbf{I}_{e}\right),
$$

where $\boldsymbol{\beta}$ is a vector of systematic effects (previously described), $\mathbf{h}$ is the vector of "random" herd effects, $\mathbf{u}$ is a vector of additive polygenic effects of animals, and $\mathbf{I}_{e}$ is a vector of residuals. The terms $\mathbf{X}, \mathbf{Z}_{1}$, and $\mathbf{Z}_{2}$ are known incidence matrices relating observations to the $\boldsymbol{\beta}, \mathbf{h}$, and $\mathbf{u}$ vectors, respectively. Because threshold $\tau$ and residual variance $\sigma_{e}^{2}$ are not identifiable in a binary threshold model, these parameters were arbitrarily set to 0 and 1, respectively. The "a priori" distributions for the remaining parameters were defined as in Sorensen et al. (1995). Sire (ram) genetic effects were assumed distributed a priori as $\mathbf{u} \sim N\left(\mathbf{0}, \mathbf{A}_{s} \sigma_{s}^{2}\right)$, where $N(\cdot)$ indicates a normal distribution, $\mathbf{A}_{s}$ is the additive genetic relationship matrix among sires, and $\sigma_{s}^{2}$ is a variance component for sire effects.

Gibbs Sampler. In this study, models were solved by performing numerical integration through the Gibbs sampling technique (Gelfand and Smith, 1990) to estimate marginal posterior densities of all unknown parameters in the models. The analysis was carried out using the program TM (http://snp.toulouse.inra .fr/ alegarra). Flat priors were used for location and dispersion parameters. A single chain of 800,000 Gibbs samples was obtained for each analysis, with a burnin of 50,000 samples. The lengths of the burn-in and chain were calculated following the methods of Raftery and Lewis (1992) and Geyer (1992), respectively. Gibbs samples were saved at intervals of 100 iterations. Features of the marginal posterior distributions of interest, the convergence analysis, and estimates of Monte Carlo error were obtained using the Bayesian Output Analysis (BOA) package (http://www.public-heath.uiowa.edu/ boa). The posterior mean was used as a point estimate of parameters of concern.

\section{RESULTS AND DISCUSSION}

\section{Prevalence of MVV and MAP Positivity}

The results from the MVV and MAP screening assays are summarized in Table 1. Regarding MVV, not all animals testing positive for MVV using the ELISA method also tested positive using the direct PCR-based assay. In contrast, all animals testing positive by the PCR-based assay also tested positive using ELISA. Therefore, for the purposes of the statistical analyses, animals were considered MVV-positive if this was ascertained by ELISA.

The overall animal prevalence of MVV-positive ewes was $43.6 \%$, with a wide range of individual variation among the 23 farms sampled: for one farm it was $0 \%$, for another $100 \%$. Our results are consistent with the study by Christodoulopoulos (2006), who reported epidemiological data gathered in Italy at the beginning of the 2000s showing high levels of prevalence throughout the country, ranging from 60 to $90 \%$. In the present study, genotyping indicated that the B strain was the only MVV strain circulating in the sampled population $(100 \%)$.

We recorded an overall animal prevalence of $10.6 \%$ for MAP. At the farm level, 19 farms (83\%) had at 
least one MAP-positive animal, whereas 4 farms had none. These values are higher than those obtained by Iarussi et al. (2019) in a large-scale survey of several breeds with different purposes (dairy, meat, and wool), where the general prevalence was $2.8 \%$ for individual animals and $45 \%$ for flocks. Those authors also reported higher values for dairy flocks. Co-positivity for MVV and MAP was relatively low, occurring in only 48 out of 1,069 sheep (4.5\%); as a consequence, the effect of co-positivity effect was not included in the statistical model. Despite the low level of co-positivity at the individual level, at least one animal tested positive for both MVV and MAP in 12 out of 23 farms, and over $20 \%$ of the ewes were co-infected in 2 farms. The low level of co-positivity agrees with a recent study by Stonos et al. (2017), who found no significant associations between MAP and SRLV infections in sheep. These authors also found no evidence of a clear relationship between the 2 infections or between the progression of the 2 diseases. However, several factors may have affected the sensitivity of their tests and, on the whole, it is likely both MVV and MAP infections were underestimated (Stonos et al., 2017). In particular, a sheep testing negative for MVV using indirect methods cannot be considered free of infection, because the antibody titer, which fluctuates during the progression of the disease, might be lower than the cut-off limit. Tests based on PCR have therefore often been used to corroborate indirect methods (Ramírez et al., 2013). Similarly, the diagnostic sensitivity of MAP ELISA tests may be affected by stage of infection, because animals may have subclinical, clinical, or shedder status (Fry et al., 2008). It is worth noting that diagnostic tests for host immune response, such as the use of ELISA to detect MAP, are not wholly reliable (Whittington et al., 2019) and the probability of false negatives is very high. In particular, the MAP ELISA tests currently available have low sensitivity levels (Li et al., 2019), with only $26 \%$ of infected cattle testing positive (Sweeney et al., 2006). Because of these limitations, tests based on direct identification of MAP, such as bacterial culture techniques or PCR using fecal samples, are preferable because they can increase the diagnostic accuracy (Whittington et al., 2019).

\section{Effects of MVV and MAP Positivity on Milk Yield, Composition, and Coagulation Properties}

The descriptive statistics and results from the linear models for milk yield, composition, and coagulation traits are reported in Table 2.

The random effect of individual farm was very high for some traits, with variabilities of $73 \%$ for daily milk yield, $49 \%$ for LBC, and around $40 \%$ for traits measuring curd firmness $\left(\mathrm{a}_{30}, \mathrm{a}_{45}, \mathrm{CF}_{\mathrm{P}}\right.$, and $\left.\mathrm{CF}_{\max }\right)$. The high incidence of the effect of farm on milk traits of small ruminant species when computed as a random factor is discussed in Vacca et al. (2018), who speculate that the higher variability in these species may be attributed to the extreme diversity of farming systems in terms of management, feeding, and breeds compared with dairy cattle farming.

The effect of MVV infection significantly affected only a few traits: LBC, curd firmness traits $\mathrm{a}_{30}$ and $\mathrm{a}_{45}$, and the curd-firming instant rate constant, $\mathrm{k}_{\mathrm{CF}}$ (Table 2). Compared with ewes testing negative, the milk samples from ewes testing positive for MVV had higher LBC values (5.69 vs. 5.52), curd firmness values about $2 \mathrm{~mm}$ lower, and $\mathrm{k}_{\mathrm{CF}}$ about $2 \% \times \min ^{-1}$ higher.

Although the data in the literature are often contradictory, they are generally in agreement with those of the present study. Indeed, MVV and other SRLV such as CAEV have a very small effect on milk yield and composition (Nord and Adnøy, 1997; Reina et al., 2009; Kaba et al., 2012). Some authors report higher SCC in milk from goats infected with CAEV (Nord and Adnøy, 1997) and from sheep infected with MVV (Christodoulopoulos, 2006). In the present study, SCS was not affected by MVV infection, even though the $P$-value tended to be significant (0.06), whereas the total number of bacterial cells was higher. Christodoulopoulos (2006) found that the udders of lactating sheep with MVV infection often exhibited subclinical indurative mastitis, which can only be identified by histological examination. In agreement with that author, we presume that the mammary epithelium cells of MVV-positive ewes are more inclined to secondary bacterial infections.

Greater losses have been reported as a result of subclinical SRLV infections in meat-producing sheep. Where ewes are positive, lambing success, lamb birth weight and growth rate, and total number of lambs weaned are negatively affected (Keen et al., 1997). Small ruminant lentiviruses can also give cause for restrictions in animal trade and higher early culling rates, which are often unquantified but have a substantial negative effect on the economic situation (Michiels et al., 2018b).

In contrast to MVV, significant effects of MAP infection were recorded on milk composition, $\mathrm{pH}$, and $\mathrm{RCT}$ (Tables 2 and 3). The highest levels of significance were for fat, protein, and casein contents, with milk samples from MAP-positive ewes having the highest concentrations. These results defy clear explanation. Ploumi et al. (2001) found that animals with the best production performance had higher prevalence of some diseases but 
Table 2. Descriptive statistics (mean and SD) and results from linear model for daily milk yield and composition, traditional coagulation properties $(\mathrm{MCP})$ and curd-firming over time $\left(\mathrm{CF}_{\mathrm{t}}\right)$ traits of individual milk samples $(\mathrm{n}=1,079)$ from Sarda ewes, with $F$-value and significance for fixed effects and the proportion of variance (in percentage) explained by the random effect of the farm

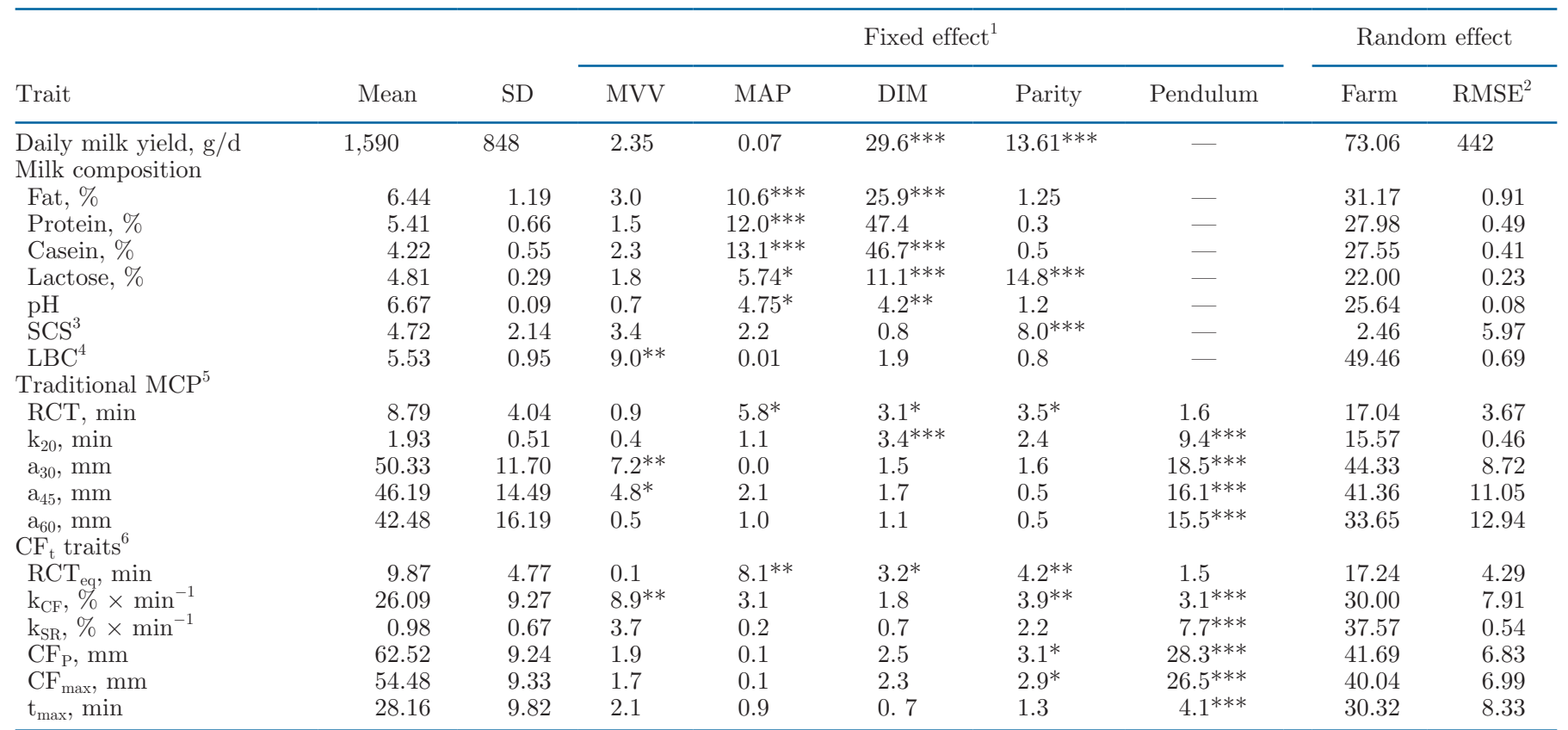

${ }^{1} \mathrm{MVV}=$ Maedi-Visna virus positivity; MAP $=$ Mycobacterium avium ssp. paratuberculosis positivity.

${ }^{2} \mathrm{RMSE}=$ root mean square error.

${ }^{3} \mathrm{SCS}: \log _{2}\left(\mathrm{SCC} \times 10^{-5}\right)+3$.

${ }^{4} \mathrm{LBC}=$ logarithmic bacterial count: $\log _{10}($ total bacterial count/1,000).

${ }^{5} \mathrm{RCT}=$ rennet coagulation time of samples coagulating within 60 min of enzyme addition; $\mathrm{k}_{20}=$ curd-firming time of samples reaching 20 mm of firmness within 60 min from enzyme addition; $\mathrm{a}_{30,45,60}=$ curd firmness at 30, 45, and 60 min after enzyme addition, respectively.

${ }^{6} \mathrm{RCT}_{\mathrm{eq}}=$ rennet coagulation time estimated using the $\mathrm{CF}_{\mathrm{t}}$ equation; $\mathrm{k}_{\mathrm{CF}}=$ curd-firming instant rate constant; $\mathrm{k}_{\mathrm{SR}}=$ syneresis instant rate constant; $\mathrm{CF}_{\mathrm{P}}=$ asymptotic potential curd firmness; $\mathrm{CF}_{\max }=$ maximum curd firmness attained within 45 min; $\mathrm{t}_{\max }=$ time at attainment of $\mathrm{CF}_{\max }$. ${ }^{*} P<0.05 ;{ }^{*} P<0.01$; ${ }^{* * *} P<0.001$.

speculated that the absence of a clear negative effect on productivity could be biased by the continuous culling of low-producing, test-positive ewes. Lactose concentrations and $\mathrm{pH}$ were also higher, and $\mathrm{RCT}$ and $\mathrm{RCT}_{\mathrm{eq}}$ were delayed by about $+10 \%$ in MAP-positive animals. Rennet coagulation time and $\mathrm{pH}$ were expected to be related because $\mathrm{pH}$ affects casein stability during the cheese-making process (Pirisi et al., 2007); the 2 traits have been found to be positively correlated (the higher the $\mathrm{pH}$, the longer the RCT) in sheep (Bittante et al., 2017).

Two papers based on a similar data set to that used in the present study (Bittante et al., 2017; Paschino et al., 2019) report that, at both the genetic and phenotypic levels, $\mathrm{pH}$ values increase when the milk samples have high microbial and somatic cell counts. However, we did not find increases in LBC and SCS in MAPpositive ewes. Hence, we can speculate that MAP was directly linked to the significant increase in $\mathrm{pH}$ and, as a consequence, $\mathrm{RCT}$ and $\mathrm{RCT}_{\mathrm{eq}}$.

\section{Heritability of Infection Status}

It might be assumed from the data shown in Table 1 that ewes from flocks in which no individuals tested positive (farm 7 for MVV, and farms 3, 4, 9, and 22 for MAP) were never exposed to the pathogens, creating a bias in the heritability estimates for susceptibility. Nonetheless, our genetic analysis was based on all data from 23 farms, because even in flocks with $0 \%$ positivity, at least one animal tested positive for the pathogens in the year preceding sampling for the present study during epidemiological studies linked or otherwise with the present paper.

Features of the marginal posterior densities for heritability estimates expressed on the liability scale are reported in Figure 1. Point estimates (mean of the posterior distributions) were 0.151 for MAP positivity and 0.072 for MVV positivity.

To our knowledge, this is the first study to report estimates obtained from the Sarda sheep breed. Previous 
Table 3. Least squares means and significance according to the effects of Maedi-Visna virus (MVV) and Mycobacterium avium ssp. paratuberculosis (MAP) positivity on daily milk yield and composition, traditional coagulation properties $(\mathrm{MCP})$, and curd-firming over time $\left(\mathrm{CF}_{\mathrm{t}}\right)$ traits of individual milk samples $(\mathrm{n}=1,079)$ from Sarda ewes

\begin{tabular}{|c|c|c|c|c|c|c|}
\hline \multirow[b]{2}{*}{ Trait } & \multicolumn{3}{|c|}{ MVV } & \multicolumn{3}{|c|}{ MAP } \\
\hline & Negative & Positive & $P$-value & Negative & Positive & $P$-value \\
\hline Daily milk yield, $\mathrm{g} / \mathrm{d}$ & 1,658 & 1,603 & NS & 1,637 & 1,625 & NS \\
\hline Fat, \% & 6.48 & 6.61 & NS & 6.39 & 6.70 & $* * *$ \\
\hline Protein, \% & 5.44 & 5.49 & NS & 5.38 & 5.56 & $* * *$ \\
\hline Casein, $\%$ & 4.24 & 4.29 & NS & 4.19 & 4.35 & $* * *$ \\
\hline Lactose, \% & 4.77 & 4.75 & NS & 4.79 & 4.73 & $*$ \\
\hline $\mathrm{pH}$ & 6.69 & 6.68 & NS & 6.68 & 6.70 & * \\
\hline $\mathrm{SCS}^{1}$ & 4.88 & 5.15 & NS & 4.87 & 5.16 & NS \\
\hline $\mathrm{LBC}^{2}$ & 5.52 & 5.69 & $* *$ & 5.61 & 5.60 & NS \\
\hline \multicolumn{7}{|l|}{ Traditional $\mathrm{MCP}^{3}$} \\
\hline $\mathrm{RCT}, \min$ & 9.36 & 9.63 & NS & 9.02 & 9.96 & * \\
\hline $\mathrm{k}_{20}, \min$ & 2.02 & 2.00 & NS & 1.98 & 2.03 & NS \\
\hline $\mathrm{a}_{30}, \mathrm{~mm}$ & 49.66 & 47.76 & $* *$ & 48.63 & 48.74 & NS \\
\hline $\mathrm{a}_{45}, \mathrm{~mm}$ & 46.02 & 44.06 & * & 44.18 & 45.90 & NS \\
\hline $\mathrm{a}_{60}, \mathrm{~mm}$ & 41.59 & 40.87 & NS & 40.52 & 41.94 & NS \\
\hline \multicolumn{7}{|l|}{$\mathrm{CF}_{\mathrm{t}}$ traits ${ }^{4}$} \\
\hline $\mathrm{RCT}_{\mathrm{eq}}, \min$ & 10.71 & 10.77 & NS & 10.09 & 11.39 & $* *$ \\
\hline $\mathrm{k}_{\mathrm{CF}}, \% \times \min ^{-1}$ & 25.23 & 27.12 & $* *$ & 26.54 & 25.81 & NS \\
\hline $\mathrm{k}_{\mathrm{SR}}, \% \times \min ^{-1}$ & 1.00 & 1.09 & NS & 1.06 & 1.03 & NS \\
\hline $\mathrm{CF}_{\mathrm{P}}, \mathrm{mm}$ & 61.79 & 61.03 & NS & 61.36 & 61.46 & NS \\
\hline $\mathrm{CF}_{\max }, \mathrm{mm}$ & 53.76 & 53.02 & NS & 53.32 & 53.45 & NS \\
\hline $\mathrm{t}_{\max }, \min$ & 28.69 & 27.73 & NS & 27.78 & 28.63 & NS \\
\hline
\end{tabular}

${ }^{1} \mathrm{SCS}: \log _{2}\left(\mathrm{SCC} \times 10^{-5}\right)+3$.

${ }^{2} \mathrm{LBC}=$ logarithmic bacterial count: $\log _{10}$ (total bacterial count/1,000).

${ }^{3} \mathrm{RCT}=$ rennet coagulation time of samples coagulating within $60 \mathrm{~min}$ of enzyme addition; $\mathrm{k}_{20}=$ curd-firming time of samples reaching $20 \mathrm{~mm}$ of firmness within $60 \mathrm{~min}$ from enzyme addition; $\mathrm{a}_{30,45,60}=$ curd firmness at 30,45 , and 60 min after enzyme addition, respectively.

${ }^{4} \mathrm{RCT}_{\text {eq }}=$ rennet coagulation time estimated using the $\mathrm{CF}_{\mathrm{t}}$ equation; $\mathrm{k}_{\mathrm{CF}}=$ curd-firming instant rate constant; $\mathrm{k}_{\mathrm{SR}}=$ syneresis instant rate constant; $\mathrm{CF}_{\mathrm{P}}=$ asymptotic potential curd firmness; $\mathrm{CF}_{\max }=$ maximum curd firmness attained within $45 \mathrm{~min} ; \mathrm{t}_{\max }=$ time at attainment of $\mathrm{CF}_{\max }$.

${ }^{*} P<0.05 ;{ }^{* *} P<0.01 ;{ }^{* * *} P<0.001$.

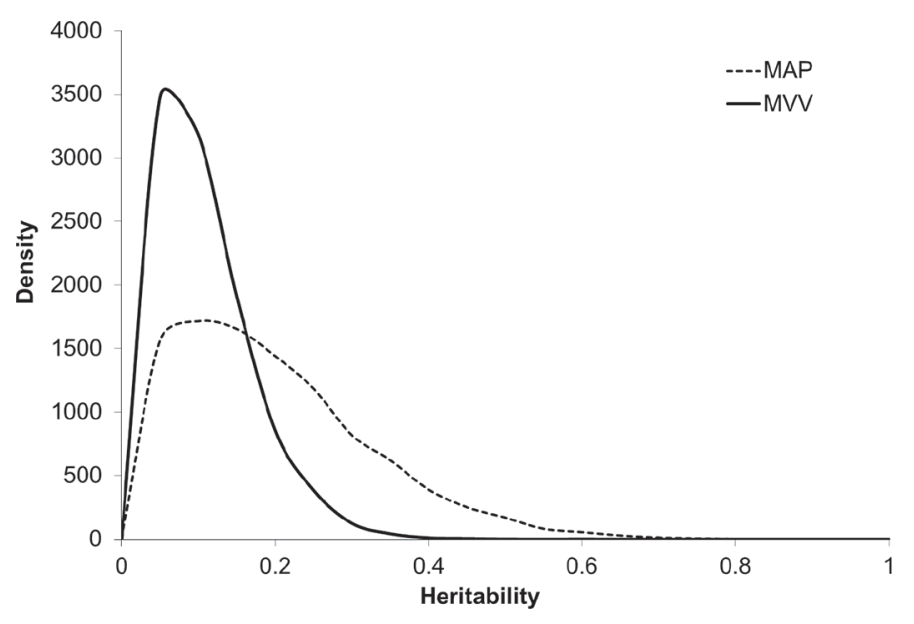

Figure 1. Marginal posterior distributions of heritability for Maedi-Visna virus (MVV) and Mycobacterium avium ssp. paratuberculosis (MAP) positivity. investigations have focused on heritability with the goal of reducing economic losses in sheep farming due to infectious and parasitic diseases. For example, a recent study by McRae et al. (2016) reports a heritability of resistance to ovine pneumonia of 0.07 . Although this may be low, and despite pneumonia being a complex disease influenced by many environmental factors other than bacteria and viruses, the authors show that the use of novel tools based on genotyping is an alternative and reliable approach to improve animal production. Higher heritability estimates, between 0.26 and 0.46 from sire models, have been recorded for fecal egg counts of gastrointestinal nematode parasites (Ngere et al., 2018).

The results from the present study, which are consistent with studies on the genetic control of MAP infection in cattle (Pozzato et al., 2010), could be the starting point for a novel approach to breeding programs aimed at selecting animals naturally resistant to MAP. Indeed, some studies have confirmed the presence of several chromosomal regions associated with 
susceptibility to MAP (Minozzi et al., 2010) and genes controlling the expression of key inflammation and immunity related responses of the host to MAP infection (Malvisi et al., 2016). In addition, given that consumers are unlikely to accept milk from persistently infected but clinically healthy sheep (Christodoulopoulos, 2006) and that control or eradication programs based on the culling and separation of positive animals are often unsuccessful, the genetic approach could be an alternative.

\section{CONCLUSIONS}

In the present study, we found that only a few milk traits were negatively affected by MVV and MAP. Milk samples from MAP-positive ewes even had higher fat, protein, and casein contents than test-negative ewes. Nonetheless, the most notable finding was that the daily milk yield of ewes was unchanged whether they tested positive or negative for MVV and MAP. Further studies are needed to investigate the seroconversion of animals across all production stages and the effects of different seroconversion statuses on milk traits. This is the first study to estimate the heritability of susceptibility to MVV and MAP infection in Sarda sheep. Although the heritability values are low, it should still be possible to develop breeding programs to select individuals for resistance to MVV and MAP infections and hence to select for increased natural resistance in sheep, thereby shifting control strategies from a hygienic to a genetic basis.

\section{ACKNOWLEDGMENTS}

This research was supported by the "Finanziamento straordinario una tantum per la ricerca, Università degli Studi di Sassari" (one-time extraordinary research grant), Sassari, Italy. The authors thank the farmers for giving access to their farms, the AIPA/APA (Provincial Farmers' Associations) of Cagliari, Nuoro, Sassari, and Oristano (Italy) for their support in sample collection, and ARA Sardegna (Regional Farmers' Association of Sardinia), Cagliari, Italy, for support in the milk analysis. The authors have not stated any conflicts of interest.

\section{REFERENCES}

Arnarson, H., A. Pálsson, M. Gudnadóttir, and V. Andrésdóttir. 2017. Maedi-visna virus persistence: Antigenic variation and latency. Comp. Immunol. Microbiol. Infect. Dis. 55:6-12. https://doi.org/ 10.1016/j.cimid.2017.08.003.

Bauman, C. A., A. Jones-Bitton, J. Jansen, D. Kelton, and P. Menzies. 2019. Evaluation of bulk tank milk PCR and bulk tank milk modified ELISA tests for the detection of paratuberculosis at the herd level in goat and sheep dairies in Ontario, Canada. J. Dairy Sci. 102:511-520. https://doi.org/10.3168/jds.2018-15020.

Begg, D., and R. Whittington. 2010. Paratuberculosis in Sheep. Pages 157-168 (Chapter 15) in Paratuberculosis: Organism, Disease, Control. M. A. Behr and D. M. Collins, ed. CAB International, Wallingford, UK.

Benavides, J., M. Fuertes, C. García-Pariente, J. Otaola, L. Delgado, J. Giraldez, J. F. García Marín, M. Carmen Ferreras, and V. Pérez. 2013. Impact of maedi-visna in intensively managed dairy sheep. Vet. J. 197:607-612. https://doi.org/10.1016/j.tvjl.2013.03 .031 .

Bittante, G., C. Cipolat-Gotet, M. Pazzola, M. L. Dettori, G. M. Vacca, and A. Cecchinato. 2017. Genetic analysis of coagulation properties, curd firming modeling, milk yield, composition and acidity in Sarda dairy sheep. J. Dairy Sci. 100:385-394. https://doi.org/ 10.3168/jds.2016-11212.

Bittante, G., B. Contiero, and A. Cecchinato. 2013. Prolonged observation and modelling of milk coagulation, curd firming, and syneresis. Int. Dairy J. 29:115-123. https://doi.org/10.1016/j.idairyj .2012.10.007.

Christodoulopoulos, G. 2006. Maedi-Visna: Clinical review and short reference on the disease status in Mediterranean countries. Small Rumin. Res. 62:47-53. https://doi.org/10.1016/j.smallrumres .2005.07.046.

Cipolat-Gotet, C., M. Pazzola, A. Ferragina, A. Cecchinato, M. L. Dettori, and G. M. Vacca. 2018. Technical note: Improving modeling of coagulation, curd firming and syneresis of sheep milk. J. Dairy Sci. 101:5832-5837. https://doi.org/10.3168/jds.2017-14256.

de Andrés, D., D. Klein, N. J. Watt, E. Berriatua, S. Torsteinsdottir, B. A. Blacklaws, and G. D. Harkiss. 2005. Diagnostic tests for small ruminant lentiviruses. Vet. Microbiol. 107:49-62. https://doi .org/10.1016/j.vetmic.2005.01.012.

Fry, M. P., J. Kruze, and M. T. Collins. 2008. Evaluation of four commercial enzyme-linked immunosorbent assays for the diagnosis of bovine paratuberculosis in Chilean dairy herds. J. Vet. Diagn. Invest. 20:329-332. https://doi.org/10.1177/104063870802000311.

Garvey, M. 2018. Mycobacterium avium subspecies paratuberculosis: A possible causative agent in human morbidity and risk to public health safety. Open Vet. J. 8:172-181. https://doi.org/10.4314/ ovj.v8i2.10.

Gelfand, A., and A. F. M. Smith. 1990. Sampling based approaches to calculating marginal densities. J. Am. Stat. Assoc. 85:398-409. https://doi.org/10.1080/01621459.1990.10476213.

Geyer, C. J. 1992. Practical Markov chain Monte Carlo. Stat. Sci. 7:473-483. https://doi.org/10.1214/ss/1177011137.

Gianola, D. 1982. Theory and analysis of threshold characters. J. Anim. Sci. 54:1079-1096. https://doi.org/10.2527/jas1982.5451079x.

González, B., R. Reina, I. Garcia, S. Andres, I. Glaria, M. Alzueta, M. I. Mora, B. M. Jugo, I. Arrieta-Aguirre, J. M. de la Lastra, D. Rodriguez, J. R. Rodriguez, M. Esteban, M. J. Grillo, B. A. Blacklaws, G. D. Harkiss, Y. Chebloune, L. Lujan, D. de Andres, and B. Amorena. 2005. Mucosal immunization of sheep with a maedi visna virus (MVV) env DNA vaccine protects against early MVV productive infection. Vaccine 23:4342-4352. https://doi.org/ 10.1016/j.vaccine.2005.03.032.

Grego, E., L. Bertolotti, A. Quasso, M. Profiti, D. Lacerenza, D. Muz, and S. Rosati. 2007. Genetic characterization of small ruminant lentivirus in Italian mixed flocks: evidence for a novel genotype circulating in a local goat population. J. Gen. Virol. 88:3423-3427. https://doi.org/10.1099/vir.0.83292-0.

Iarussi, F., P. Paradies, R. Sardaro, G. Rubino, D. Scaltrito, E. Pieragostini, and F. Petazzi. 2019. Epidemiology and risk factors of $M y-$ cobacterium avium subspecies paratuberculosis in semi-extensive dairy sheep and goat farms of Apulia, southern Italy. Small Rumin. Res. 177:89-96. https://doi.org/10.1016/j.smallrumres.2019 .06 .016 .

IDF. 2000. Milk- First experiences with automatic flow cytometric determination of total bacterial count in raw milk. IDF 358:2000. International Dairy Federation (IDF), Brussels, Belgium.

IDF. 2006. International Dairy Federation. Milk-Enumeration of somatic cells - Part 2: Guidance on the operation of fluoro-optoelec- 
tronic counters. IDF 148-2:2006. International Dairy Federation (IDF), Brussels, Belgium.

ISO/IDF. 2004. Milk. Quantitative determination of bacteriological quality. Guidance for establishing and verifying a conversion relationship between routine method results and anchor method results. ISO 21187/IDF 196:2004. International Organization for Standardization (ISO), Geneva, Switzerland, and International Dairy Federation (IDF), Brussels, Belgium.

ISO/IDF. 2013. Milk and liquid milk products. Determination of fat, protein, casein, lactose and pH content. ISO 9622/IDF 141:2013. ISO, Geneva, Switzerland, and IDF, Brussels, Belgium.

Jarvis, L. S., and P. Valdes-Donoso. 2018. A selective review of the economic analysis of animal health management. J. Agric. Econ. 69:201-225. https://doi.org/10.1111/1477-9552.12131.

Kaba, J., N. Strzałkowska, A. Jóźwik, J. Krzyżewski, and E. Bagnicka. 2012. Twelve-year cohort study on the influence of caprine arthritis-encephalitis virus infection on milk yield and composition. J. Dairy Sci. 95:1617-1622. https://doi.org/10.3168/jds.2011-4680.

Keen, J. E., L. L. Hungerford, E. T. Littledike, T. E. Wittum, and J. Kwang. 1997. Effect of ewe ovine lentivirus infection on ewe and lamb productivity. Prev. Vet. Med. 30:155-169. https://doi.org/10 .1016/S0167-5877(96)01101-4.

Li, L., J. P. Bannantine, J. J. Campo, A. Randall, Y. Grohn, M. A. Schilling, R. Katani, J. Radzio-Basu, L. Easterling, and V. Kapur. 2019. Identification of sero-diagnostic antigens for the early diagnosis of Johne's disease using MAP protein microarrays. Sci. Rep. 9:17573. https://doi.org/10.1038/s41598-019-53973-x.

Malvisi, M., F. Palazzo, N. Morandi, B. Lazzari, J. L. Williams, G. Pagnacco, and G. Minozzi. 2016. Responses of bovine innate immunity to Mycobacterium avium ssp. paratuberculosis infection revealed by changes in gene expression and levels of microRNA. PLoS One 11:e0164461. https://doi.org/10.1371/journal.pone .0164461 .

McMahon, D. J., and R. J. Brown. 1982. Evaluation of Formagraph for comparing rennet solutions. J. Dairy Sci. 65:1639-1642. https: //doi.org/10.3168/jds.S0022-0302(82)82390-4.

McRae, K. M., H. J. Baird, K. G. Dodds, M. J. Bixley, and S. M. Clarke. 2016. Incidence and heritability of ovine pneumonia, and the relationship with production traits in New Zealand sheep. Small Rumin. Res. 145:136-141. https://doi.org/10.1016/ j.smallrumres.2016.11.003.

Michiels, R., E. Van Mael, C. Quinet, N. R. Adjadj, A. B. Cay, and N. De Regge. 2018a. Comparative analysis of different serological and molecular tests for the detection of small ruminant lentiviruses (SRLVs) in Belgian sheep and goats. Viruses 10:696. https://doi .org/10.3390/v10120696.

Michiels, R., E. Van Mael, C. Quinet, S. Welby, A. B. Cay, and N. De Regge. 2018b. Seroprevalence and risk factors related to small ruminant lentivirus infections in Belgian sheep and goats. Prev. Vet. Med. 151:13-20. https://doi.org/10.1016/j.prevetmed.2017.12.014.

Minozzi, G., L. Buggiotti, A. Stella, F. Strozzi, M. Luini, and J. L. Williams. 2010. Genetic loci involved in antibody response to Mycobacterium avium ssp. paratuberculosis in cattle. PLoS One 5:e11117. https://doi.org/10.1371/journal.pone.0011117.

Ngere, L., J. M. Burke, J. L. M. Morgan, J. E. Miller, and D. R. Notter. 2018. Genetic parameters for fecal egg counts and their relationship with body weights in Katahdin lambs. J. Anim. Sci. 96:1590-1599. https://doi.org/10.1093/jas/sky064.

Nord, K., and T. Adnøy. 1997. Effects of infection by caprine arthritis-encephalitis virus on milk production of goats. J. Dairy Sci. 80:2391-2397. https://doi.org/10.3168/jds.S0022-0302(97)76190 $-3$.

OIE (World Organisation for Animal Health). 2019. Manual of diagnostic tests and vaccines for terrestrial animals, chapter 3.7.2 Accessed Nov. 18, 2019. https://www.oie.int/standard-setting/ terrestrial-manual/access-online/.

Paschino, P., G. M. Vacca, M. L. Dettori, and M. Pazzola. 2019. An approach for the estimation of somatic cells' effect in Sarda sheep milk based on the analysis of milk traits and coagulation properties. Small Rumin. Res. 171:77-81. https://doi.org/10.1016/j .smallrumres.2018.10.010.
Pazzola, M., C. Cipolat-Gotet, G. Bittante, A. Cecchinato, M. L. Dettori, and G. M. Vacca. 2018a. Phenotypic and genetic relationships between indicators of the mammary gland health status and milk composition, coagulation, and curd firming in dairy sheep. J. Dairy Sci. 101:3164-3175. https://doi.org/10.3168/jds.2017-13975.

Pazzola, M., M. L. Dettori, C. Cipolat-Gotet, A. Cecchinato, G. Bittante, and G. M. Vacca. 2014. Phenotypic factors affecting coagulation properties of milk from Sarda ewes. J. Dairy Sci. 97:72477257. https://doi.org/10.3168/jds.2014-8138.

Pazzola, M., G. Stocco, P. Paschino, M. L. Dettori, C. Cipolat-Gotet, G. Bittante, and G. M. Vacca. 2018b. Modeling of coagulation, curd firming, and syneresis of goat milk. J. Dairy Sci. 101:70277039. https://doi.org/10.3168/jds.2018-14397.

Pirisi, A., A. Lauret, and J. P. Dubeuf. 2007. Basic and incentive payments for goat and sheep milk in relation to quality. Small Rumin. Res. 68:167-178. https://doi.org/10.1016/j.smallrumres .2006.09.009.

Ploumi, K., V. Christodoulou, E. Vainas, A. Lymberopoulos, A. Xioufis, A. Giouzeuiannis, E. Paschaleri, and I. Ap Dewi. 2001. Effect of maedi-visna virus infection on milk production in dairy sheep in Greece. Vet. Rec. 149:526-527. https://doi.org/10.1136/vr.149 .17.526.

Pozzato, N., R. A. Juste, J. M. Garrido, and G. Vicenzoni. 2010. Vaccination and genetic selection: Novel strategies for bovine paratuberculosis control. Large Anim. Rev. 16:211-217.

Raftery, A. E., and S. M. Lewis. 1992. How many iterations in the Gibbs Sampler? Pages 763-774 in Bayesian Statistics IV. J. M. Bernardo, J. O. Berger, A. P. Dawid, and A. F. M. Smith, ed. Oxford Univ. Press, New York, NY.

Ramírez, H., R. Reina, B. Amorena, D. de Andrés, and A. H. Martínez. 2013. Small ruminant lentiviruses: Genetic variability, tropism and diagnosis. Viruses 5:1175-1207. https://doi.org/10.3390/ v5041175.

Reina, R., E. Berriatua, L. Lujan, R. Juste, A. Sanchez, D. de Andres, and B. Amorena. 2009. Prevention strategies against small ruminant lentiviruses: An update. Vet. J. 182:31-37. https://doi.org/ 10.1016/j.tvjl.2008.05.008.

Roger, P. A. 2008. The impact of disease and disease prevention on sheep welfare. Small Rumin. Res. 76:104-111. https://doi.org/10 .1016/j.smallrumres.2007.12.005.

Sardaro, R., E. Pieragostini, G. Rubino, and F. Petazzi. 2017. Impact of Mycobacterium avium subspecies paratuberculosis on profit efficiency in semi-extensive dairy sheep and goat farms of Apulia, southern Italy. Prev. Vet. Med. 136:56-64. https://doi.org/10 .1016/j.prevetmed.2016.11.013.

Shook, G. E. 1993. Genetic improvement of mastitis through selection on somatic cell count. Vet. Clin. North Am. Food Anim. Pract. 9:563-577. https://doi.org/10.1016/S0749-0720(15)30622-8.

Sorensen, D. A., S. Andersen, D. Gianola, and I. Korsgaard. 1995 Bayesian inference in threshold models using Gibbs sampling. Genet. Sel. Evol. 27:229-249. https://doi.org/10.1186/1297-9686 $-27-3-229$.

Stonos, N., C. Bauman, P. Menzies, S. K. Wootton, and N. A. Karrow. 2017. Prevalence of small ruminant lentivirus and Mycobacterium avium ssp. paratuberculosis co-infection in Ontario dairy sheep and dairy goats. Can. J. Vet. Res. 81:155-159.

Straub, O. C. 2004. Maedi-Visna virus infection in sheep. History and present knowledge. Comp. Immunol. Microbiol. Infect. Dis. 27:1-5. https://doi.org/10.1016/S0147-9571(02)00078-4.

Sweeney, R. W., R. H. Whitlock, S. McAdams, and T. Fyock. 2006. Longitudinal study of ELISA seroreactivity to Mycobacterium avium ssp. paratuberculosis in infected cattle and culture-negative herd mates. J. Vet. Diagn. Invest. 18:2-6. https://doi.org/10.1177/ 104063870601800102.

Vacca, G. M., M. Pazzola, M. L. Dettori, E. Pira, F. Malchiodi, C. Cipolat-Gotet, A. Cecchinato, and G. Bittante. 2015. Modeling of coagulation, curd firming, and syneresis of milk from Sarda ewes. J. Dairy Sci. 98:2245-2259. https://doi.org/10.3168/jds.2014 $-8902$.

Vacca, G. M., G. Stocco, M. L. Dettori, E. Pira, G. Bittante, and M. Pazzola. 2018. Milk yield, quality, and coagulation properties of 6 
breeds of goats: Environmental and individual variability. J. Dairy Sci. 101:7236-7247. https://doi.org/10.3168/jds.2017-14111.

Whittington, R., K. Donat, M. F. Weber, D. Kelton, S. S. Nielsen, S. Eisenberg, N. Arrigoni, R. Juste, J. L. Sáez, N. Dhand, A. Santi, A. Michel, H. Barkema, P. Kralik, P. Kostoulas, L. Citer, F. Griffin, R. Barwell, M. A. S. Moreira, I. Slana, H. Koehler, S. V. Singh, H. S. Yoo, G. Chávez-Gris, A. Goodridge, M. Ocepek, J. Garrido, K. Stevenson, M. Collins, B. Alonso, K. Cirone, F. Paolicchi, L. Gavey, M. T. Rahman, E. de Marchin, W. Van Praet, C. Bauman, G. Fecteau, S. McKenna, M. Salgado, J. Fernández-Silva, R. Dziedzinska, G. Echeverría, J. Seppänen, V. Thibault, V. Fridriksdottir, A. Derakhshandeh, M. Haghkhah, L. Ruocco, S. Kawaji, E. Momotani, C. Heuer, S. Norton, S. Cadmus, A. Agdestein, A. Kampen, J. Szteyn, J. Frössling, E. Schwan, G. Caldow, S. Strain, M. Carter, S. Wells, M. Munyeme, R. Wolf, R. Gurung, C. Verdugo, C. Fourichon, T. Yamamoto, S. Thapaliya, E. Di Labio, M. Ekgatat, A. Gil, A. N. Alesandre, J. Piaggio, A. Suanes, and J. H. de Waard. 2019. Control of paratuberculosis: Who, why and how.
A review of 48 countries. BMC Vet. Res. 15:198. https://doi.org/ 10.1186/s12917-019-1943-4.

Windsor, P. A. 2015. Paratuberculosis in sheep and goats. Vet. Microbiol. 181:161-169. https://doi.org/10.1016/j.vetmic.2015.07.019.

Wright, S. 1934. An analysis of variability in number of digits in an inbred strain of Guinea pigs. Genetics 19:506-536.

\section{ORCIDS}

Michele Pazzola (ํ) https://orcid.org/0000-0001-5685-0416

Giantonella Puggioni ( ) https://orcid.org/0000-0001-9013-8203

Maria N. Ponti ® https://orcid.org/0000-0002-9247-3299

Rosario Scivoli $\odot$ https://orcid.org/0000-0002-5219-6928

Maria L. Dettori ( https://orcid.org/0000-0001-5413-0335

Alessio Cecchinato (i) https://orcid.org/0000-0003-3518-720X

Giuseppe M. Vacca @ https://orcid.org/0000-0003-3110-5211 